\title{
Erratum
}

\section{7 on fiction, femininity, and fashion: an interview with Linda grant}

Emma Parker

Correction to: Feminist Review (2010) 96, 127-134.

doi: $10.1057 / f r .2009 .20$

We regret that the opening sentence of this article was published incorrectly as:

'One of the Britain's leading writers, Linda Grant is an award-winning journalist and author of four highly lauded novels: ...'

This should have appeared as follows:

'One of Britain's leading writers, Linda Grant is an award-winning journalist and author of four highly lauded novels: ...'

Additionally, the author biography was omitted. This should have appeared as follows:

\section{about the author}

Emma Parker is a senior lecturer in English at the University of Leicester. She has published essays on Margaret Atwood, Angela Carter, Toni Morrison, Jeanette Winterson, Michèle Roberts and Rose Tremain, is author of Kate Atkinson's Behind the Scenes at the Museum: A Reader's Guide (2002), editor of Contemporary British Women Writers (2004), and associate editor of the journal Contemporary Women's Writing. She is also a founding member of the Contemporary Women's Writing Association (www.the-cwwa.org).

doi: $10.1057 /$ fr. 2011.1 